\title{
Mecillinam for the treatment of Typhoid fever
}

Hadi Jusuf, Primal Sudjana

\begin{abstract}
Abstrak
Mesilinam, suatu asam 6-amidinopenisilanat, mempunyai aktifitas yang kuat terhadap kuman Gram-negatif, termasuk Salmonella spp. Uji coba obat ini terhadap demam tifoid telah pernah dilakukan di luar negeri, tetapi obat ini belum pernah diuji di Indonesia. Untuk tujuan tersebut dilakukan suatu studi komparatif terbuka untuk menentukan kegunaan dan keamanan dari obat ini untuk pengobatan demam tifoid. Empat puluh dua pasien (20 laki-laki dan 22 wanita, dengan umur antara 14 hingga 46 tahun) dengan demam tifoid yang dirawat di RSU Hasan Sadikin dari tahun 1995 hingga 1996, telah merdapat pengobatan dengan mesilinam (400 mg untuk 25 pasien dan $800 \mathrm{mg}$ untuk 17 pasien, masing-masing empat kali sehari, selama 14 hari). Diagnosis dari penderita ditegakkan atas dasar gambaran klinis dan/ atau dengan hasil biakan (darah dan sumsum tulang). Respons klinis dan bakteriologis didapatkan pada masingmasing $85,7 \%$ dan 100\%. Penurunan panas terjadi setelah 4 hari. Satu penderita mengalami ensefalopati toksik dan kekambuhan terjadi pada $3(7,1 \%)$ penderita. Dua penderita mengeluh adanya gejala mual selama pengobatan, meskipun demikian pengobatan tetap diteruskan. Kesimpulan: mesilinam dapat dipergunakan sebagai obat alternatif untuk pengobatan penderita demam tifoid, bila terdapat kontra indikasi untuk penggunaan obat yang lazim dipakai.
\end{abstract}

\begin{abstract}
Mecillinam, a novel 6-amidinopenicillanic acid, has high activity againts Gram negative bacteria, including Salmonella spp. It has been investigated in the treatment of typhoid fever abroad, but has not in Indonesia. We conducted non comparrative open study to determine the efficacy and safety of the drug in typhoid fever. 42 patient (20 males, 22 females, ranging in age from 14 to 46 years) with typhoid fever admitted to Hasan Sadikin General Hospital from 1995 to 1996 were treated with mecillinam (400 mg in 25 patients, 800 mg in 17 patients, qid, for 14 days). Diagnosis was made on the base of clinical feature and/or culture Blood, Bone marrow). Clinical and bacteriologic responses were documented in $85.7 \%, 100 \%$, respectively. Defervescence of fever was 4 days. One patient developed toxic encephalopathy and relapse occured in $3(7.1 \%)$ patients. 2 patients complained nausea during treatment, but the medication was still continued. In conclusion, mecillinam could be used as an alternative drug in typhoid fever treatment if there is contraindication to standard drugs.
\end{abstract}

Infectious Disease Unit, Dept. of Internal Medicine,

Medical Faculty, Padjadjaran University

Hasan Sadikin General Hospital, Bandung-Indonesia. 